\title{
MANAJEMEN PENDIDIKAN KARAKTER DI SMA DE BRITTO YOGYAKARTA
}

\author{
Y. Rimawan Prihartoyo, Siti Irene Astuti Dwiningrum \\ YPG-SMA GAMA, Universitas Negeri Yogyakarta \\ wawanpunokawan@yahoo.co.id
}

\begin{abstract}
Abstrak
Pendidikan karakter di Indonesia dinilai gagal. Penyebabnya diyakini bahwa manajemen pendidikan karakter di sekolah belum berlangsung sebagaimanamestinya. Penelitian dilakukan untuk mengetahui dan mendiskripsikan bagaimana manajemen pendidikan karakter dilakukan di SMA De Britto dan apa saja faktor pendukung dan penghambatnya. SMA De Britto memiliki landasan yang kokoh di bidang pendidikan karakter, dan tertuang dalam Pedoman Kolese De Britto. Pendidikan karakter SMA De Britto dibagi dalam tiga tahapan besar yaitu pendidikan ekskursi, live in, dan retret. Metode penelitian adalah deskriptif kualitatif. Hasil penelitian menunjukkan bahwa manajemen pendidikan karakter di SMA De Britto telah berjalan sebagaimana mestinya. Direncanakan dengan matang melibatkan orang tua dan berpedoman pada visi misi secara kuat, diorganisasikan dengan baik, dilaksanakan dengan dinamis, dikontrol dan diawasi dengan tegas oleh pejabat yang ditunjuk, dan dievaluasi secara komprehensif melalui cara personalis, pendampingan, dan retret/geladi rohani. Faktor penghambat adalah orang tua peserta didik yang meragukan program pendidikan karakter De Britto. Sedangkan pendukung dapat diketahui adanya yayasan yang kuat, jaringan alumni yang kuat, dana mantap, lokasi strategis, SDM terpilih/unggul, dan lain-lain.
\end{abstract}

Kata kunci: karakter, pendidikan karakter, manajemen pendidikan karakter

\section{CHARACTER EDUCATION MANAGEMENT IN DE BRITTO HIGH SCHOOL YOGYAKARTA}

\section{Abstract}

Character education in Indonesia is considered failed. The cause is believed that character education in the school management has not should be done. The study was conducted to determine and describe how the character management education management is done in De Britto high school and what are the factors supporting and inhibiting. De Britto High School has a solid foundation in the field of character education, and stipulated in the Guidelines for Colleges De Britto. De Britto High School character education is divided into three major phases, namely educational excursions, live in, and retreats. Research is descriptive qualitative method. The results showed that the character of management education in De Britto High School has been running as it should. Carefully planned involving parents and guided by the strong of vision and mission, well organized, implemented with dynamic, controlled and supervised by officials appointed by the firm, and comprehensively evaluated through cura personalist, mentoring, and retreat/spiritual rehearsals. Limiting factor is the parents of students who doubted De Britto character education programs. While the discovery of a foundation can support a strong, strong alumni network, steady funding, strategic location, selected human resources/excel, and others.

Keywords: character, character education, character education management 


\section{Pendahuluan}

Mutu pendidikan yang rendah disebabkan oleh peran sekolah yang belum optimal dalam menjalankan fungsinya. Sekolah dinilai gagal ketika tidak mampu melahirkan orang-orang berpendidikan yang dewasa dan berperilaku baik serta berbudaya. Seharusnya sekolah tidak hanya mengembangkan ilmu, ketrampilan, dan teknologi, tetapi juga mengembangkan aspek-aspek lain seperti: kepribadian, etik, moral, dan lain-lain. Sekolah memiliki nilai kontributif dalam rangka pembentukan karakter anak bangsa. Pendidikan karakter di sekolah diberikan untuk pengembangan kemampuan intelektual dan kemampuan moral.

Sekolah berperan dalam pendidikan karakter. Dengan pendidikan karakter diharapkan akan memperbaiki mutu pendidikan. Sekolah perlu mengoptimalkan kemampuannya dalam melakukan transfer pengetahuan yang bersifat multidimensional. Keseimbangan hasil pendidikan di bidang intelektual dan kemampuan moral menjadi semakin mendesak untuk ditelaah kembali. Degradasi moral melanda generasi muda Indonesia. Bahkan sebagian pakar menyebutkan bahwa Indonesia sedang mengalami krisis multidimensional.

Thomas Lickona, mengungkapkan bahwa ada sepuluh tanda-tanda zaman yang harus diwaspadai. Jika tanda-tanda ini sudah ada, itu berarti bahwa sebuah bangsa sedang menuju jurang kehancuran. Tanda-tanda yang dimaksud adalah (Ratna Megawangi, 2004: p.7-8):

Meningkatnya kekerasan di kalangan remaja, seperti tawuran,penggunaan bahasa dan kata-kata yang memburuk, seperti mengolok-olok teman sebayanya, atau berkata tidak sopan pada pendidik/guru, pengaruh peer-group yang kuat dalam tindak kekerasan, termasuk tindakan bulying yang menjadi sorotan di kalangan remaja sekolah, meningkatnya perilaku merusak diri, seperti penggunaan narkoba, alkohol dan seks bebas, semakin kaburnya pedoman moral baik dan buruk, menurunnya etos kerja, semakin rendahnya rasa hormat kepada orang tua dan guru, rendahnya rasa tanggung jawab individu dan warga negara, membudayanya perilaku ketidakjujuran, adanya rasa saling curiga dan kebencian di antara sesama.

Perilaku menyimpang yang terjadi tersebut banyak dilakukan oleh orang muda terdidik, karena para pelaku penyimpangan itu disebutkan sebagai pelajar, anggota legislatif, pegawai atau petugas peradilan, dan lain-lain. Orang yang bekerja adalah orang dalam usia produktif atau usia muda. Mereka adalah hasil dari pendidikan di Indonesia. Gambaran tersebut merupakan cermin kegagalan proses pendidikan kita. Kegagalan tersebut adalah dalam hal penanaman nilai-nilai karakter sebagai manusia yang berakhlak mulia, berketuhanan, menghormati dan menghargai nilai-nilai humanis dan kebangsaan, sehingga manusia muda terdidik adalah manusia yang memiliki perkembangan pribadi sehat dan produktif atau berkarakter.

Salah satu upaya mengatasi krisis karakter bangsa dilakukan melalui proses pendidikan yang komprehensif, berkesinambungan dan tidak hanya mementingkan aspek formal-kognitif saja. Lilis Ummi Fa' iezah, S.Pd.,MA., seorang guru di MTsN Yogyakarta 1 menulis pandangannya tentang arti penting pendidikan karakter dan dimuat pada SKH Kedaulatan Rakyat tanggal 6 Oktober 2012. Beliau menulis:

Peninjauan ulang terhadap kurikulum sekolah yang menurut banyak pihak terlalu sarat muatan perlu menjadi perhatian. Menjadikan pendidikan karakter sebagai suatu mata pelajaran utuh, bukan sekedar diselipkan pada mata pelajaran lain rasanya perlu direalisasikan sebagai dasar pembentukan pribadi luhur. Mengingat pentingnya masalah ini, tidak ada alasan bagi kita semua untuk tidak serius menangani masalah anarkisitas pelajar dalam rangka menyelamatkan generasi muda.

Pendidikan bukan hanya menjadikan seseorang lebih pandai ataupun memiliki pengetahuan kognitif, tetapi pendidikan juga bertujuan mengembangkan pribadi 
anak didik agar menjadi manusia seutuhnya. Melalui pendidikan haruslah dapat dibentuk kelompok masyarakat terdidik yang ditandai dengan semakin meratanya keadaan damai, demokratis, berkeadilan, berdaya saing, maju dan sejahtera, sehat, mandiri, beriman, berkesadaran hukum dan lingkungan, bertoleransi, menguasai ilmu pengetahuan dan teknologi, memiliki etos kerja tinggi serta berdisiplin. Arah pendidikan demikian ini selaras dengan Undang-Undang RI No. 20 tahun 2003, tentang Sistem Pendidikan Nasional pasal 1 ayat 1 yaitu:

Pendidikan merupakan usaha sadar dan terencana untuk mewujudkan suasana belajar dan proses pembelajaran agar peserta didik secara aktif mengembangkan potensi dirinya untuk memiliki kekuatan spiritual keagamaan, pengendalian diri, kepribadian, kecerdasan, akhlak mulia, serta keterampilan yang diperlukan dalam hidupnya.

Dari uraian tersebut di atas dapat dimaknai bahwa karakter adalah watak, tabiat, akhlak, atau kepribadian seseorang yang terbentuk dari hasil internalisasi berbagai kebajikan (virtues) yang diyakini dan digunakan sebagai landasan untuk cara pandang, berpikir, bersikap, dan bertindak. Kebajikan terdiri atas sejumlah nilai, moral, dan norma, seperti jujur, berani bertindak, dapat dipercaya, dan hormat kepada orang lain. Penggabungan dari berbagai kebajikan tersebut juga di-pengaruhi berbagai hal. Dalam pandangan filsuf Michael Novak disebutkan;

Character is a compatible mix of all those virtues identified by religious traditions, literary stories, the sages, and persons of common sense down through history. (Lickona, 1992: p. 50).

Jadi pengertian pendidikan karakter adalah suatu usaha pengembangan dan mendidik karakter seseorang, yaitu kejiwaan, akhlak dan budi pekerti sehingga menjadi lebih baik. Pendidikan karakter adalah suatu sistem penanaman nilai-nilai karakter kepada warga sekolah yang meliputi komponen pengetahuan, kesadaran atau kemauan, dan tindakan untuk melak- sanakan nilai-nilai tersebut. Pendidikan karakter memiliki esensi dan makna yang sama dengan pendidikan moral dan pendidikan akhlak. Tujuannya adalah membentuk pribadi anak, supaya menjadi manusia yang baik, warga masyarakat, dan warga negara yang baik.

Keberhasilan pendidikan karakter di sekolah sangat ditentukan oleh manajemen pendidikan yang dijalankan sekolah. Hal ini mensyiratkan bahwa pendidikan karakter adalah sebuah proses pembelajaran yang tidak bisa dijalankan secara parsial dan terpisah-pisah. Proses pembelajaran ini didukung berbagai komponen, yakni: guru, siswa, tujuan, materi, sarana/media dan metodologi. Faktorfaktor tersebut mempunyai peranan yang penting dalam mengupayakan efektivitas proses pembelajaran yang berlangsung. Demikian juga sekolah/satuan pendidikan memiliki peranan yang penting dalam rangka pelaksanaan pendidikan karakter.

Satuan pendidikan merupakan wahana pembinaan dan pengembangan karakter siswa yang dilakukan secara formal di lingkungan sekolah. Adapun pemberdayaannya dapat dilakukan melalui: (a) regulasi tentang pengintegrasian pembelajaran karakter dalam semua mata pelajaran; (b) meningkatkan kapasitas sekolah sebagai wahana pendidikan karakter melalui pelatihan para guru; (c) penyediaan sumber-sumber belajar yang terkait dengan upaya pengembangan karakter siswa; dan (d) pemberian penghargaan kepada satuan pendidikan yang telah berhasil mengembangkan budaya karakter. (Darmiyati Zuchdi, dkk., 2012: p. 35)

Pada sisi lain, guru adalah faktor yang strategis dalam proses pembelajaran. Guru adalah agen pembelajaran sekaligus agen perubahan, manakala mendidik dimaknai sebagai proses transfer pengetahuan dan proses pendewasaan. Guru dituntut memiliki seperangkat kompetensi, yaitu: kepribadian, pedagogis, profesional, dan sosial. Kompetensi pedagogis menyaratkan bahwa ia harus memiliki kemampuan manajerial dalam mengelola kegiatan pembelajaran, yang menyangkut: 
planning, organizing, staffing, leadership, dan controlling untuk dapat mencapai tujuan pendidikan secara efektif dan efesien. Dengan kemampuan manajerial, guru akan mampu menciptakan suatu iklim belajar yang aktif, inovatif, kreatif, efektif dan menyenangkan.

Keseluruhan proses tersebut diwujudkan ke dalam suatu kegiatan manajemen, yaitu suatu proses yang kontinyu bermuatan kemampuan dan keterampilan khusus yang dimiliki oleh seseorang atau kelompok orang untuk melakukan kegiatan baik sendiri-sendiri maupun bersama orang lain dalam mengkoordinasi dan menggunakan segala sumber daya untuk mencapai tujuan secara produktif, efektif, dan efisien. Mengacu pada pemahaman manajemen yang demikian itu, maka fungsi manajemen di bidang pendidikan berpijak pada prinsip planning, organizing, actuating, controling, dan evaluation disingkat POACE (Engkoswara, 2010: p.93).

Atas dasar pertimbangan tersebut, menarik untuk melakukan penelitian pelaksanaan manajemen pendidikan karakter di sekolah menengah umum khususnya di Yogyakarta sebagai kota pendidikan/kota pelajar. Banyak sekolah-sekolah di Yogyakarta yang memiliki prestasi dan menonjol di bidang pendidikan karakter. Salah satunya adalah SMA De Britto Yogyakarta, sekolah swasta karya misi yang bersifat terbuka untuk umum dan semua siswanya adalah laki-laki.

Permasalahan dalam penelitian ini yaitu bagaimanakah manajemen pendidikan karakter di De Britto dilaksanakan. Hal ini meliputi lima unsur pokok dalam manajemen yaitu bagaimana perencanaan pendidikan karakter di de Britto? Bagaimanakah pengorganisasian pendidikan karakter di De Britto? Bagaimana perwujudan pendidikan karakter tersebut? Bagaimana kontrol/pengawasan pendidikan karakter di De Britto? Bagaimanakah evaluasinya dilakukan? Permasalahan lain adalah apa yang menjadi faktor pendukung maupun penghambat dalam pendidikan karakter di De Britto? Sedangkan tujuan penelitian adalah mendiskripsikan dan mengetahui tentang perencanaan, pengorganisasian, perwujudan, pengawasan, dan evaluasi pendidikan karakter di De Britto; serta mengetahui faktor pendukung dan penghambat dalam pendidikan karakter di De Britto.

Secara ideal, penelitian ini diharapkan dapat bermanfaat bagi beberapa aspek, diantaranya: secara teoritis memberikan sumbangan keilmuan terhadap perkembangan ilmu manajemen pendidikan terutama berkenaan dengan manajemen pendidikan karakter di sekolah, sebagai bahan referensi bagi peneliti-peneliti lain yang akan melakukan penelitian bidang yang sama pada masa yang akan datang. Secara praktis bagi institusi yang diteliti, sebagai masukan yang konstruktif dalam mengelola manajemen pendidikan karakter di sekolah, menjadi bahan masukan dan sekaligus referensi bagi kepala sekolah, beserta wakil kepala sekolah, guru, komite sekolah dan seluruh warga sekolah dalam mengembangkan pendidikan karakter di sekolah. Bagi para pengambil kebijakan, sebagai salah satu acuan dalam mengambil keputusan dan kebijakan tentang pengembangan pendidikan karakter di sekolah.

\section{Metode Penelitian}

Penelitian ini menggunakan pendekatan diskriptif kualitatif. Data dan temuan dituliskan dalam bentuk kata serta kalimat dan diuraikan dalam paparan yang bersifat mendiskripsikan, untuk kemudian ditarik suatu kesimpulan.

\section{Waktu dan Tempat Penelitian}

Penelitian dilakukan diawali dengan pra penelitian pada Bulan November 2012 dan secara intensif penelitian dilaksanakan selama Bulan Maret 2013 sampai dengan akhir Bulan April 2013 di SMA De Britto Yogyakarta Jl. Adisucipto No. 161 Yogyakarta.

\section{Subjek Penelitian}

Subyek penelitian adalah sumber penelitian yang dibagi dalam dua jenis yaitu informan utama dan informan. Informan utama adalah Kepala Sekolah, 
dan informan lain adalah Wakil kepala Sekolah Bidang Kesiswaan, Wakil Kepala Sekolah Bidang Kurikulum, Pamong Siswa dan Guru Bimbingan Konseling.

Data, Intrumen, dan Teknik Pengumpulan Data

Data terdiri dari dua macam yaitu data primer dan data sekunder. Data primer adalah dokumen sekolah dan keterangan kepala sekolah. Data sekunder adalah keterangan yang didapat dari sumber lain. Data diperoleh dengan cara wawancara mendalam dengan subyek penelitian dan mempelajari dokumen yang berhubungan dengan penelitian. Instrumen penelitian adalah peneliti sendiri sebagaimana sifat penelitian kualitatif.

Teknik Analisis Data

Pada prinsipnya, analisis data dilakukan bersamaan dengan proses pengumpulan data. Analisis data dilakukan dengan mengatur urutan data, mengorganisasikan dalam bentuk pola tertentu, mengkategorikan dan memilah data sesuai uraian pokoknya.

\section{Hasil Penelitian dan Pembahasan}

SMA De Britto didirikan oleh suatu komunitas Imam-Imam Serikat Yesus yang dikenal dengan nama Jesuit. SMA De Britto merupakan Kolese yang secara umum mengambil sikap bersama dalam olah budi dan olah pikir membangun generasi muda bangsa. Sekolah di bawah Yayasan Johanes De Britto ini memiliki organisasi yang khas. yaitu tunduk pada Pedoman Kolese yang dibuat oleh pemilik yayasan, yaitu para Imam Serikat Jesus atau disebut Imam Jesuit yang memiliki pembesar ordo bertempat di Roma Italia. Pedoman Kolese tersebut bersifat mengikat SMA De Britto dan harus ditaati. Berisi visi dan misi yang sangat kuat, dan berisi pedoman umum yang selalu dievaluasi setiap 10 tahun sekali. Di dalam Pedoman Kolese juga dimuat arah dasar pendidikan dan pengembangan siswa De Britto, dimana isi pokoknya adalah menjadikan De Britto sebagai tempat mengolah diri membentuk pribadi unggul dan berkarakter.
Sebagai Kolese SMA De Britto tunduk pada satu pimpinan yang bersifat kolegial, yaitu pimpinan Serikat Jesuit sebagai pemilik yayasan, pengurus yayasan sebagai pengelola sekolah, dan direksi sekolah sebagai pelaksana di lapangan. Direksi sekolah terdiri dari pengurus yayasan dan kepala sekolah serta wakilwakilnya. Pada konteks ini jelas bahwa kepemimpinan kolegium itu sangat mempengaruhi jalannya organisasi De Britto.

Rencana besar pendidikan karakter telah disiapkan oleh para pendahulu dan pendiri De Britto yang sampai sekarang menjadi pedoman utama, dituangkan dalam buku berjudul Pedoman Kolese De Britto. Di dalam buku ini juga dimuat tentang profil siswa. Penetapan tentang profil siswa yang hendak dihasilkan di SMA De Britto menjadi dasar untuk menyusun program pendidikan karakter. Pedoman Kolese De Britto menjadi jiwa bagi semua yang terlibat di dalamnya. Tidak terkecuali pengurus yayasan tertinggi De Britto pun tunduk dan menjalankan pedoman tersebut. Hal itulah yang menjadikan SMA De Britto teguh dan kuat dalam menjalankan pendidikan karakter bagi siswa.

Buku Pedoman Kolese ini berisi panduan/pedoman umum yang bersifat terbuka. Diperbarui setiap sepuluh tahun sekali sehingga isinya selalu disesuaikan dengan situasi dan perkembangan jaman. Sebagai sebuah pedoman yang disepakati bersama, buku ini menjadi semacam buku suci nya De Britto. Sehingga tidak ada satu alasanpun untuk tidak mengacu pada buku tersebut dalam setiap kebijakan yang dikeluarkan oleh semua pemangku kepentingan SMA De Britto.

SMA Kolese De Britto menerapkan Paradigma Pedagogi Ignasian dalam menyusun kurikulum pendidikannya. Tujuannya untuk mendidik siswa agar mengembangkan belajar mandiri sehingga siswa mampu mencari dan mencerna informasi yang diperlukan dan membiasakan diri untuk proses belajar seumur hidup.

Pedagogi Ignasian ialah cara para pengajar harus mendampingi siswa dalam 
pertumbuhan, perkembangan, dan pembentukan kepribadian siswa, yang dilandasi spiritualitas Santo Ignatius. Pedagogi meliputi pandangan hidup dan visi dari berbagai ideal manusia untuk dididik. Pedagogi juga memberikan kriteria pilihan sarana untuk dipakai dalam proses pendidikan. Oleh karena itu, pedagogi ini tidak boleh direduksi menjadi metodologi semata-mata. (Buku Pedoman Siswa 1 SMA De Britto, 2013: p. 20-21)

Paradigma Pedagogi Ignasian merupakan sebuah alat yang praktis dan sebuah perangkat yang efektif untuk meningkatkan kinerja guru dan siswa dalam proses kegiatan belajar mengajar. Secara luas, paradigma ini merupakan cara bertindak yang membantu siswa berkembang menjadi manusia yang berkompeten, bertanggung jawab, dan berbelas kasih. Pedagogi Ignasian mencakup lima langkah pokok, yaitu: konteks, pengalaman, refleksi, aksi, dan evaluasi.

Hal ini merupakan perwujudan visi dan misi SMA Kolese De Britto. Dalam visinya disebutkan Kolese De Britto sebagai komunitas pendidikan berjuang untuk membantu proses pembentukan pribadi siswa menjadi pemimpin-pemimpin pelayanan yang kompeten, berhati nurani benar, dan berkepedulian pada sesama demi kemuliaan Allah yang lebih besar. Sedang sedangkan misinya disebutkan dengan dilandasi semangat kristiani dan spiritualitas Ignasian, komunitas Kolese De Britto bertekad untuk:

a) membentuk siswa menjadi pemimpin yang humanis, melayani, berani berjuang bagi sesama, dan berwawasan kebangsaan, serta menghayati nilai-nilai luhur bangsa Indonesia;

b) membantu siswa menjadi pribadi yang berkembang secara utuh, optimal, dan seimbang;

c) mengembangkan siswa menjadi pribadi yang jujur, disiplin, mandiri, kreatif, dan mau bekerja keras.

Kesatuan dari pedagogi Ignasian, visi, dan misi De Britto diwujudkan dalam kurikulum pendidikan. Kurikulum SMA De Britto adalah bagian dari proses pendidikan Kolese De Britto yang merupakan aktualisasi dari visi, misi, dan tujuan pendidikan. Pendampingan pribadi siswa melalui kurikulum pendidikan diarahkan kepada profil siswa yang ditetapkan berikut ini: siswa yang memiliki penghayatan iman yang terintegrasi dalam kehidupan; pejuang untuk sesama; mandiri, kreatif dan komunikatif; optimal dan seimbang; disiplin, bekerja keras dan berusaha gigih.

Kolese De Britto sebagai karya kerasulan Serikat Jesus mengambil bagian dalam usaha mewujudkan tujuan pendidikan secara umum dan tujuan khusus pendidikan Yesuit. Berpijak pada visi dan misi yang telah dirumuskan, pendidikan di Kolese De Britto bertujuan membantu proses pembentukan siswa menjadi pemimpin-pemimpin pelayanan yang meneladan Yesus Kristus dengan kepribadian yang utuh, optimal dan seimbang, jujur, disiplin, mandiri, kreatif, mau bekerja keras, humanis, selalu sedia melayani, dan berani berjuang bagi sesama.

Pedoman Kolese memberikan gambaran umum tentang pendidikan karakter di SMA De Britto. Pendidikan karakter SMA De Britto tidak diatur secara khusus dalam kurikulum. Tetapi pada muatan lokal kurikulum De Britto dicantumkan program Spiritualitas Ignasian yaitu semangat dasar pendiri Jesuit Santo Ignatius. Ignasian adalah sebutan bagi para pengikut Santo Ignatius. Program lain dalam muatan lokal adalah pendidikan nilai-nilai, dan pendampingan personal.

Pendidikan karakter SMA De Britto memiliki ciri khas pendidikan pada lembaga pendidikan milik komunitas Jesuit yaitu: Kolese De Britto merupakan wadah dan wahana Katolik, Kolese De Britto merupakan pusat belajar, Kolese De Britto merupakan wadah dan wahana pembinaan kepribadian, Kolese De Britto merupakan keluarga, Kolese De Britto Peduli kepada siswa yang kurang mampu.

Berdasarkan pedoman tersebut, SMA De Britto mengelola pendidikan karakter bagi siswanya dengan suatu program yang matang dan berkesinambungan. Program 
pendidikan karakter bukan semata-mata dibuat sebagai paket sekolah yang kaku tetapi bergerak dinamis mengikuti tuntutan dan kebutuhan.

SMA De Britto mengelompokkan program pendidikan karakter ke dalam tiga tahapan utama, yaitu: pendidikan ekskursi untuk kelas $\mathrm{X}$, live in untuk kelas $\mathrm{XI}$, dan retret/geladi rohani untuk kelas XII. Pendidikan ekskursi dimaksudkan bahwa siswa diajak untuk melihat dan mengamati dari luar tentang aneka macam peristiwa dalam kehidupan dan lingkungan untuk kemudian diolah secara akademik dalam bentuk karya tulis pribadi tentang apa, bagaimana, mengapa suatu peristiwa itu terjadi. Live in yaitu suatu perwujudan keterlibatan secara langsung para siswa di dalam proses kehidupan dan lingkungan dengan berada bersama masyarakat, menjalani hidup, dan berusaha survive tanpa bantuan orang tua atau sekolah. Hal ini dilakukan bersama kelompok masyarakat yang dinilai berada di strata bawah, miskin dan terpinggirkan. Retret dimaksudkan sebagai metode refleksi diri, permenungan atas siapa dirinya, mau apa, bagaimana, dan mengapa ada. Hal ini sebagai bentuk evaluasi diri dan upaya reflektif atas upaya pembentukan diri selama mengikuti pendidikan di De Britto.

Aktivitas kegiatan pendidikan karakter De Britto dimulai dengan suatu perencanaan program yang disosialisasikan kepada orang tua siswa di awal tahun ajaran baru, dimana dalam kegiatan tersebut sangat dimungkinkan adanya masukan dan usulan dari orang tua tentang kegiatan apa yang bisa dilakukan dalam rangka pendidikan karakter siswa. Pada tahapan berikutnya, program tersebut diorganisasikan sesuai tahapan sebagaimana sudah disebutkan.

Sedangkan perwujudan sehari-hari, De Britto menetapkan suatu bentuk kegiatan berupa keteladanan guru, Bimbingan Konseling, ekstrakurikuler, pendidikan nilai-nilai, perwalian, LKTD, kegiatan rohani, pendampingan pribadi, pembentukan presidium siswa sebagai pengganti organisasi
OSIS, temu alumni secara periodik berkesinambungan, dan lain-lain. Semua aktivitas tersebut bertujuan membantu siswa sampai pada pencapaian kesadaran sebagai manusia pribadi yang bebas. Kesadaran akan kebebasan sebagai pribadi inilah yang juga mendasari semangat pendidikan di De Britto, yaitu pendidikan bebas.

Masyarakat banyak mengirimkan dan menyampaikan pertanyaan kepada sekolah tentang mengapa Kolese De Britto memakai istilah pendidikan bebas. Diketahui bahwa yang dimaksud bukanlah suatu pendidikan ke arah anarki: suatu sistem yang bebas dari peraturan yang perlu untuk kehidupan bermasyarakat. Bukan pula suatu sistem yang merestui segala penyelewengan dari nilai-nilai yang dicita-citakan, melainkan terutama adalah suatu sikap dalam usaha para pendidik bersama peserta didik, untuk bersamasama mencari pengarahan dalam tindaktanduk, berlandas pada pengakuan bahwa karunia manusia yang paling asasi dan luhur adalah kebebasannya yang harus diprioritaskan dalam proses pembentukan kepribadian.

Para pengajar SMA Kolese De Britto sependapat dan sepakat bahwa mereka tidak hanya menyampaikan bahan pelajaran saja (mengajar), tetapi sekaligus mendidik. Artinya, menolong, membantu mencarikan pengarahan kepada anak didik supaya dapat memilih jalan hidup serta perbuatan sendiri, tanpa sebelumnya atau sesudahnya menutup rapat-rapat kemungkinan pemilihan lain.

Pendidikan bebas bukan sematamata bebas melakukan apa saja, tetapi dalam kebebasan itu siswa belajar memahami bahwa ada batasan berupa kebebasan orang lain. Hal inilah yang menjadi ciri khas pendidikan De Britto. De Britto meyakini bahwa dalam kebebasan sebagai manusia itulah karakter dapat terbentuk. Karena dengan demikian seseorang akan bebas memilih atau tidak memilih, melakukan atau tidak melakukan secara sadar tanpa pemaksaan dan kewajiban. Pada tahapan ini tampak bahwa De Britto dengan tegas memilih apa yang 
tidak dipilih oleh sekolah lain. Sikap yang tegas dan jelas inilah tampaknya yang menjadikan De Britto eksis dan bertahan dari waktu ke waktu.

Kemampuan dan kesanggupan untuk menentukan pilihan pribadi siswa bagi tindak-tanduknya dan jalan hidupnya sendiri dengan tanggung jawab pribadi, tidak lain adalah kebebasannya. Sikap yang harus mendasari pendidik dalam mendidik adalah menolong, bukan mengambil alih, mencarikan pengarahan (membimbing) pada anak didik. Anak didik adalah subyek, yaitu 'sumber, pembawa, pemilik' aktivitas manusia yang dikaruniai kebebasan untuk "melihat" dan "memilih" secara manusia, yaitu secara bebas apa yang (dapat) memberikan arti kepada hidupnya sebagai manusia (hidup yang berperikemanusiaan). Prinsip dasar pendidikan bebas itulah yang mendasari De Britto dalam mengelola kurikulum belajar siswa. Demi memegang teguh pada kesepakatan De Britto sebagai kolese, maka disusunlah kurikulum pendidikan De Britto.

Di bidang kendali dan pengawasan atau kontrol pendidikan karakter terutama adalah tanggungjawab Kepala Sekolah. Kepala sekolah tidak secara langsung terjun dalam pengelolaan dan pelaksanaan pendidikan karakter. Sekolah mendorong dan memfasilitasi, bahkan cenderung mengikuti keinginan warga sekolah khususnya siswa, sejauh hal itu berada dalam koridor semangat pedagogi Ignasian sebagaimana diuraikan sebelumnya. Demikian juga pihak yayasan tidak mendikte atau mengarahkan agar sekolah mengikuti arahan yayasan dalam kegiatan mendidik siswa. Yayasan secara sadar tidak terlibat dan tidak ikut menentukan ke arah mana para siswa hendak dibawa.

Dalam tata organisasi De Britto, tanggung jawab Kepala sekolah di bidang pendidikan karakter ini didelegasikan kepada pejabat khusus. Yayasan De Britto menempatkan seorang pejabat yang disebut Pamong Siswa. Tugas utamanya adalah mengelola pendidikan karakter mulai dari perencanaan sampai evaluasi. Pamong siswa juga memberikan pen- dampingan bersifat cura personalis, yaitu pendampingan secara pribadi sesuai kebutuhan siswa. Semua bentuk pembinaan siswa dan kontrol pendidikan karakter dilakukan Pamong Siswa. Pamong bertanggung jawab kepada Kepala Sekolah. Pamong memberikan rekomendasi kepada Wakil Kepala Sekolah Bidang Kurikulum atas kemajuan siswa terutama berhubungan dengan perkembangan pribadi/perkembangan karakter pribadi siswa. Rekomendasi ini juga bisa berupa catatan bahwa seorang siswa belum layak untuk naik kelas ataupun lulus sekolah.

De Britto membantu proses pembentukan pribadi siswa secara optimal dan seimbang sesuai dengan bakat-bakatnya. Kegiatan pendampingan siswa menekankan cura personalis. Seluruh kegiatan pendampingan siswa yang tidak langsung berkaitan dengan pengajaran menjadi tanggung jawab Pamong. Pamong mengkoordinasi kegiatan pendampingan siswa dalam bidang bimbingan dan konseling, perwalian, ekstrakurikuler, pembinaan rohani, kepresidiuman, bea siswa, dan tata tertib siswa. Untuk mengefektifkan kegiatan pendampingan siswa, pamong mengoordinasi pertemuan antara pihak sekolah dengan orang tua/wali siswa yang diselenggarakan setiap semester gasal.

Di luar acara pertemuan yang secara resmi diselenggarakan sekolah itu, diharapkan komunikasi dan kerjasama pendampingan anak tetap berlangsung. Saat anak berhalangan tidak bisa masuk mengikuti kegiatan sekolah, itulah saat komunikasi dan kerjasama orang tua dan sekolah diharapkan terjadi. Saat anak mengalami kesulitan belajar, kesulitan bergaul, kesulitan-kesulitan pribadi, saat itulah kesempatan komunikasi dan kerjasama diwujudkan. Bapak-ibu sebagai orang tua dapat menghubungi pihak sekolah baik pamong, subpamong, bimbingan konseling maupun wali kelas berkaitan dengan pendampingan dan perkembangan anak.

Di dalam manajemen pendidikan, evaluasi adalah salah satu cara untuk mengukur keberhasilan peserta didik di dalam menyerap dan memahami materi 
yang diajarkan dan atau dilatihkan. Secara umum digunakan angka-angka sebagai indikator. Misalnya dengan nilai 10 berarti anak tersebut dinyatakan berhasil dan dengan nilai 1siswa dinyatakan gagal.

Pada tahapan evaluasi, De Britto tidak memberikan penilaian keberhasilan pendidikan karakter dengan nilai kuantitatif. Evaluasi dilakukan pada saat siswa naik ke kelas XII dengan cara wajib mengikuti retret bagi yang Kristiani dan mengikuti Geladi Rohani bagi yang non Kristiani. Pada kegiatan ini siswa diajak untuk berefleksi tentang sejauh mana mereka sudah memanfaatkan waktu selama mengikuti pendidikan di De Britto untuk membentuk dan membangun dirinya. Refleksi tentang profil siswa De Britto diberikan oleh pembimbing untuk mengajak siswa sampai pada tahapan memaknai proses pembentukan dirinya.

Retret menjadi bagian wajib dalam merenungkan dan merefleksi diri sejauh mana pribadi siswa dibentuk dan terbentuk oleh dirinya sendiri, maupun lingkungannya selama menempuh studi di SMA De Britto. Dengan retret, siswa dibawa dan diajak oleh pembimbing untuk masuk ke dalam pemahaman proses belajar terus menerus untuk lebih mendewasakan diri dan pribadi.

Demikianlah tampak secara nyata bahwa pelaksanaan kegiatan pendidikan karakter di De Britto dipersiapkan secara matang dan menjadi program berkelanjutan sesuai jenjang kelas yang ditempuh peserta didik. Proses pembelajaran menjadi sarana untuk membantu siswa memahami kebermaknaan hidupnya, sekolah sebagai lembaga memberi dorongan dan fasilitas untuk mencapainya, dan pembinaan siswa dilakukan sekolah melalui aktifitas siswa sebagai wadah untuk mewujudkan kreatifitas dan pembentukan profil diri siswa. Hal ini telah diuraikan pada bagian awal penulisan tesis bahwa pendidikan karakter secara terpadu di SMA dilaksanakan melalui proses pembelajaran, manajemen sekolah, dan kegiatan pembinaan kesiswaan.

Pengelolaan pendidikan karakter di

SMA De Britto tersebut menunjukkan bahwa aspek penting dalam proses pendidikan yang tidak hanya memberikan pengetahuan kognitif melainkan juga harus bersifat afektif sangatlah penting. Perpaduan kurikulum nasional dengan muatan kurikulum lokal khas De Britto menunjukkan suatu manajemen pendidikan yang bersifat dinamis dilakukan oleh SMA De Britto. Integrasi yang terkontrol dan direncanakan dengan baik telah dilakukan SMA De Britto di dalam mewujudkan tugas lembaga pendidikan, yaitu sekolah yang berfungsi sebagai agen perubahan. Hal ini juga menunjukkan bahwa dinamika kepemimpinan sekolah memberikan andil yang besar dalam pengelolaan manajemen sekolah.

SMA De Britto telah memiliki konsep dasar yang kuat di dalam menjalankan tugas dan kewajiban sekolah sebagai the agent of change bagi para siswanya. SMA De Britto menyadari betul bahwa pendidikan haruslah menghasilkan insan berkarakter.

SMA De Britto tidak menempatkan pendidikan karakater sebagai kurikulum tersendiri. Tetapi pendidikan karakter terintegrasi ke dalam setiap mata pelajaran. Dengan demikian semua guru bertanggung jawab atas keberlangsungan pendidikan karakter tersebut. Tetapi dengan memilih muatan lokal kurikulum berupa Spiritualitas Ignasian, pendidikan nilainilai, dan pendampingan, menunjukkan De Britto telah mengintegrasikan pendidikan karakter di sekolah secara cermat.

SMA De Britto mengaplikasikan pengertian manajemen pendidikan secara terbuka. Manajemen sebagai sekumpulan orang yang memiliki tujuan bersama dan bekerja sama untuk mencapai tujuan yang telah ditetapkan. Dalam manajemen terkandung pengertian pemanfaatan sumberdaya untuk tercapainya tujuan. Sumberdaya adalah unsur-unsur dalam manajemen, yaitu manusia (man), bahan (materials), mesin/peralatan(machines), metode/ cara kerja (methods), modal uang (money), informasi (information). Sumberdaya bersifat terbatas, sehingga tugas manajer mengelola keterbatasan sumber daya secara efisien dan efektif agar tujuan tercapai. 
Proses manajemen adalah proses yang berlangsung terus menerus, dimulai dari: membuat perencanaan dan pembuatan keputusan (planning); mengorganisasikan sumberdaya yang dimiliki (organizing); menerapkan kepemimpinan untuk menggerakkan sumberdaya (actuating); melaksanakan pengendalian (controlling), dan melakukan evaluasi.

Di dalam konteks manajemen sekolah, SMA De Britto telah berhasil menjalankan dan mengembangkan visi pendidikan melalui sebuah proses manajemen yang baik. Salah satu visi pendidikan disebutkan bahwa kegiatan pembinaan kesiswaan adalah berkembangnya potensi, bakat dan minat secara optimal, serta tumbuhnya kemandirian dan kebahagiaan peserta didik yang berguna untuk diri sendiri, keluarga dan masyarakat. Misi kegiatan pembinaan kesiswaan adalah (1) menyediakan sejumlah kegiatan yang dapat dipilih oleh peserta didik sesuai dengan kebutuhan, potensi, bakat, dan minat mereka; (2) menyelenggarakan kegiatan yang memberikan kesempatan peserta didik mengeskpresikan diri secara bebas melalui kegiatan mandiri dan atau kelompok. Hal ini juga tampak dalam prestasi yang dicapai siswa SMA De Britto. Siswa Kolese De Britto mempunyai segudang prestasi di bidang olahraga maupun non-olah raga. Untuk bidang olah raga, secara spesifik De Britto terkenal dengan prestasi basketnya. Sementara untuk non-olah raga, De Britto terkenal dengan prestasi debatnya. (dengan prestasi yang melampaui taraf daerah), fotografi (yang rutin mengadakan pameran), teater, dan cheerleaders (yang anggotanya tentunya laki-laki semua).

Tampak sekali bahwa menilai keberhasilan pendidikan karakter di SMA De Britto tidak bisa dengan angka-angka. Melainkan dengan mendengar dan memberikan kesempatan kepada setiap pribadi siswa untuk mengungkapkan diri dan pengalamannya selama mengenyam pendidikan di De Britto secara bebas dan tidak dibatasi oleh larangan-larangan. Mereka berefleksi lewat retret. Pada kesempatan retret tersebut juga diberikan kepada para siswa untuk menyatakan isi hatinya kepada para orang tua masing-masing melelalui sebuah surat. Kemudian surat tersebut diberikan kepada para orang tua melalui pertemuan di sekolah dan harus dibalas juga oleh orang tua dan diberikan kepada siswa melalui sekolah. Di sini De Britto menunjukkan bahwa proses pendidikan bukan semata-mata tanggung jawab sekolah, melainkan juga tanggung jawab orang tua siswa.

Pada sisi lain, hambatan datang dari orang tua siswa. Setiap dilakukan sosialisasi program pendidikan karakter pada awal tahun ajaran baru, orang tua selalu mempertanyakan secara panjang lebar tentang aman tidaknya kegiatan diluar sekolah yang dipilih De Britto. Bahkan seringkali tidak mengijinkan anaknya mengikuti kegiatan pendidikan karakter. Dalam pandangan orang tua aktivitas live in dimana siswa harus hidup di tengah dan bersama masyarakat yang dianggap terpinggirkan, kotor, miskin, penyakitan, dan lain-lain adalah hal berbahaya bagi anakanak mereka. Perdebatan yang panjang lebar tentang hal ini seringkali menjadikan sosialisasi berlarut-larut dan justru merugikan sekolah serta siswa. Namun keadaan demikian tidak menjadikan sekolah berkompromi dengan orang tua. Penjelasan yang sabar dari pimpinan sekolah bisa diterima sebagaian terbesar dari orang tua. Dan jika ada yang tetap keberatan, sekolah mempersilakan untuk mengambil kembali anaknya dari De Britto.

Sikap tegas dari pimpinan sekolah yang demikian mampu menenangkan orang tua siswa sehingga program pendidikan karakter De Britto berlangsung dengan baik. Sikap tegas sekolah yang demikian ini telah memberikan kontribusi yang nyata bagi berlangsungnya proses pendidikan karakter di SMA De Britto.

Pada aspek dukungan, diketahui bahwa SMA De Britto berlokasi di tempat yang sangat strategis. Di tepi jalan utama Yogyakarta Solo. Berada di tengah kota, tetapi karena lokasi yang sangat luas, dengan bangunan berkeliling yang kokoh, 
lingkungan di dalam SMA De Britto sangat asri. Pohon-pohon besar tumbuh dan hidup. Faktor pendukung lain adalah Yayasan De Britto yang sangat kuat didukung dari Serikat Imam Jesuit, sumber dana baik dari orang tua maupun lembaga swasta atau perusahaan yang juga lancar, dukungan alumni dengan yayasan alumni yang bersinergi dengan sekolah sejak lama menjadikan SMA De Britto semakin kokoh. Sumber Daya Manusia yang dimiliki adalah pilihan dengan seleksi ketat. Sehingga pengelolaan sekolah menjadi lancar dan dinamis. Kekuatan visi dan misi yang dijabarkan secara jelas dan tegas oleh para pendiri SMA De Britto semakin memantapkan keberlangsungan sekolah ini.

Berdasarkan uraian di atas, tampak bahwa pedidikan karakter SMA De Britto dirancang, dijalankan, dan dievaluasi berdasarkan prinsip manajemen yang terintegrasi dalam prinsip POACE, yaitu planning, organizing, actuating, controlling, dan evaluation. Prinsip fungsi manajemen pendidikan ini diaktualisasikan dalam kegiatan nyata di SMA De Britto.

\section{Simpulan}

Manajemen Pendidikan Karakter di SMA De Britto Yogyakarta telah berjalan sebagaimanamestinya. Hal ini dapat dilihat sebagai berikut:

a. SMA De Britto merencanakan pendidikan karakter dengan berpegang pada Pedoman Kolese yang ditetapkan oleh pimpinan tertinggi Serikat Yesuit yaitu pemilik Yayasan SMA De Britto. Prinsip dasar pendidikan bebas De Britto menjadi pedoman yang harus ditaati. Sifat terbuka dan demokratis digunakan dalam menyusun program utama pendidikan karakter, yaitu: pendidikan ekskursi, live in, dan retret/geladi rohani.

b. Dalam pengorganisasian pendidikan karakter SMA De Britto melalui 3 tahapan utama yaitu: pendidikan ekskursi bagi kelas X, live in bagi kelas XI, dan retret/geladi rohani bagi kelas XII.

c. Pada tahap pelaksanaan/actuating, SMA De Britto menerapkan aktivitas dan program keteladanan, ekstrakurikuler, ibadat rohani, perwalian, presidium siswa, pembinaan rohani, pelatihan kepemimpinan, tata tertib siswa, pendidikan nilai-nilai, dan bimbingan konseling.

d. Pada tataran kontrol/pengawasan, SMA De Britto menempatkan seorang pejabat yang disebut Pamong Siswa sebagai penanggung jawab pendidikan karakter. TugaS Pamong Siswa termasuk melakukan pendampingan bersifat cura personalis dan penerapan sanksi sebagai metode olah diri.

e. Pada tahap evaluasi, SMA De Britto tidak membuat evaluasi ujian tentang keberhasilan program pendidikan karakter tetapi menyelenggarakan kegiatan retret/geladi rohani sebagai media mengevaluasi diri dan pengokohan jati diri siswa sesuai profil siswa yang telah ditetapkan.

Hal yang menghambat dalam manajemen pendidikan karakter di SMA De Britto adalah orang tua siswa. Manajemen pendidikan karakter di SMA De Britto yang fleksibel dan dinamis, terbuka untuk penyesuaian dengan kebutuhan siswa, seringkali membuat orang tua siswa tidak bisa menerima sepenuhnya. Kekuatiran akan keamanan, dan jaminan lainnya terhadap program pendidikan karakter di SMA De Britto sering menjadi perdebatan panjang pada pertemuan dengan orang tua wali siswa pada awal tahun ajaran baru.

Hal-hal yang mendukung SMA De Britto dapat disebutkan sebagai berikut: lokasi sekolah yang sangat strategis, Yayasan De Britto yang kuat, sumber dana yang mantap, sumber daya manusia yang terpilih dan terlatih, alumni yang mendukung secara riil.

Saran

Untuk lebih memantapkan manajemen pendidikan karakter di SMA De Britto akan menjadi lebih baik jika pedoman pengelolaan pendidikan karakter yang sudah ada dibuat dalam bentuk buku kerja tersendiri. Selama ini meskipun ada buku pedoman Kolese De Britto, tetapi 
diskripsi dan tata organisasi serta implementasi pendidikan karakter di SMA De Britto masih tersebar dalam beberapa buku pedoman dan ada yang merupakan kebiasaan yang tidak dituliskan.

Dengan demikian jika cetak biru atau grand design manajemen pendidikan karakter di SMA De Britto dapat dibukukan tersendiri, akan menjadi kekayaan bagi berkembangnya warga SMA De Britto dan sangat dimungkinkan menjadi contoh bagi sekolah lain. Sehingga degradasi moral bangsa yang disebut sebagai tanda gagalnya pendidikan karakter di Indonesia sebagaimana diuraikan pada awal tesis ini dapat dieliminir dengan menerapkan manajemen pendidikan karakter di sekolah secara baik.

Peran kepemimpinan sekolah yang jelas, tegas, dan terbuka akan memberikan dampak yang positif bagi berkembangnya lembaga dan komunitas sekolah. Model kepemimpinan yang terbuka, partisipatif, dan bersedia mendengar mampu memberikan dukungan akan kinerja seluruh staf sehingga organisasi bergerak sesuai yang dicita-citakan. Demikian halnya dengan kepemimpinan SMA De Britto untuk pengelolaan pendidikan karakter siswa. Keterbukaan dalam memberikan ruang yang bebas bagi guru dan staf serta siswa dalam mengaktualisasikan pendidikan karakter mampu membentuk sekolah yang sekolah unggul dalam pendidikan karakter.

Metode pengembangan pendidikan karakter yang dilakukan SMA De Britto membuahkan hasil yang baik, dimana ditunjukkan dengan pencapaian prestasi sekolah, keunggulan alumni, maupun situasi siswa di dalam lingkungan yang terus berubah dan seringkali menimbulkan dampak negatif di masyarakat. Tetapi SMA De Britto dapat keluar dari situasi negatif tersebut, sehingga model pendidikan karakter di De Britto bisa ditiru dan dikembangkan oleh sekolah lain.

\section{Daftar Pustaka}

Andi Prastowo. (2011). Memahami metodemetode penelitian. Yogyakarta: ArRuzz Media
(2012). Metode penelitian kualitatif dalam perspektif rancangan penelitian. Yogyakarta: Ar-Ruzz Media.

Bogdan R.C., \& Biklen, SK. (1992). Qualitatif research for an education: introduction to theory and methodes, Needham Heights: MA., Ally Bacon

Clark, Power. F. (1997). Understanding the character in character education, University of Notre Dame. Di-unduh dari http://www.tigger.uic.edu/ inucci/MoralED/articles/powerun der.htmlTanggal 4 Januari 2013.

Darmiyati Zuchdi, Zuhdan Kun Prasetya., et.all. (2012). Model pendidikan karakter terintegrasi dalam pembelajaran dan pengembangan kultur sekolah. Yogyakarta: UNY Press.

Doni Koesoema, A. (2010). Pendidikan karakter strategi mendidik anak di zaman global. Jakarta: PT. Grasindo.

Hidayatullah, M. F. (2010). Pendidikan karakter: membangun peradaban bangsa. Surakarta: Yuma Pustaka.

Lickona, T. (1992). Educating for character, how our schools can teach respect and responsibility. New York: Bantam Books.

. (2004). Character matters. New York: A Touchstone Book.

M .Berkowitz \& M.Bier. (2006). What works in character education. Washington.

Rusman. (2011). Manajemen kurikulum. Jakarta: PT Raja Grafindo Persada.

Ratna Megawangi. (2004). Pendidikan karakter; solusi tepat untuk membangun bangsa. Jakarta: Indonesia Heritage Foundation.

SMA Kolese De Britto. (2010). Buku pedoman siswa 1. Yogyakarta: SMA Kolese De Britto.

SMA Kolese De Britto. (2012). Buku pedoman siswa 2 tahun 2012 - 2013. Yogyakarta: SMA De Britto.

Undang-Undang RI No. 20 Tahun 2003. Sistem pendidikan nasional. Jakarta: Biro Hukum dan Organisasi Sekjen Depdiknas.

Yayasan De Britto. (2003). Pedoman Kolese De Britto. Yogyakarta: Yayasan De Britto. 